Copyright (C) 2018 by the Kalmyk Scientific Center of the Russian Academy of Sciences

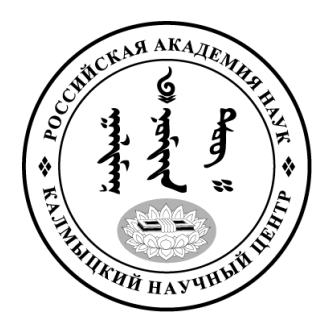

Published in the Russian Federation

Oriental Studies (Previous Name: Bulletin of the Kalmyk Institute for

Humanities of the Russian Academy of Sciences)

Has been issued as a journal since 2008

ISSN: 2619-0990; E-ISSN: 2619-1008

Vol. 38, Is. 4, pp. 52-67, 2018

DOI 10.22162/2619-0990-2018-38-4-52-67

Journal homepage: https://kigiran.elpub.ru

УдК 39

\title{
Вопросы этнической идентификации калмыцких буддистов первой трети XX в. в контексте современных проблем исследования этнической истории калмыков*
}

\author{
Эльза Петровна Бакаева \\ ${ }^{1}$ доктор исторических наук, зам. директора Калмыцкого научного центра РАН (358000, Рос- \\ сия, г. Элиста, ул. им. И.К.Илишкина, д. 8). ORCID: 0000-0002-5188-1202. E-mail: bakaevaep@ \\ yandex.ru
}

Аннотация. В статье анализируются вопросы этнической и конфессиональной идентичности в контексте актуальных проблем исследования этнической истории калмыков. Освещаются дискутируемые вопросы исследования этногенеза калмыцкого народа, активно продвигаемые в интернет-пространстве концепции единой этнической идентичности калмыков и западных монголов (ойратов), а также представления о сложении единой идентичности калмыков в начале XX в. Для анализа причин появления последней идеи к исследованию привлечены документы, отложившиеся в архивных фондах, относящиеся к деятельности буддийских общин калмыков в начале XX в. Показано, что современные представления о позднем формировании единой идентичности калмыков основываются на наличии свидетельств о бытовавшей в указанный период не только калмыцкой, но и иной идентификации. Однако стратифицированная этническая идентичность, отразившаяся в документах калмыков-буддистов, свидетельствует как о сохранности границ этнических групп в пространстве, определенных спецификой административно-территориального деления, так и о выполнении ею функций этнических ментальных (духовных) маркеров.

Ключевые слова: этническая идентичность, конфессиональная идентичность, калмыки, этнические группы, буддисты, документы

* Работа выполнена при финансовой поддержке Программы фундаментальных исследований президиума РАН «Культурно-сложные общества: понимание и управление» (объединенный проект «Калмыки: ламаиты, буддисты, христиане (опыт исследования конфессиональной и этнической идентичности калмыков в России), «Дуализм имперской политики по управлению инородцами в XIX - начале XX вв.: аккультурация или ассимиляция»). 
В монголоведческой литературе сложилась концепция происхождения калмыков, согласно которой новый этнос сформировался на основе разных западномонгольских групп, прикочевавших в российское Поволжье в XVII в. [Эрдниев 1970; Авляев 2002; История Калмыкии ... 2009, I; Калмыки 2010; и др.]. Вместе с тем до настоящего времени остается немало лакун в исследовании вопросов происхождения народа и этнической идентичности калмыков.

Так, дискутируемым остается вопрос: откуда пришли ойратские группы? Очевидный ответ - из Центральной Азии и Южной Сибири - требует уточнения в географическом и социально-политическом аспектах, а популярный тезис «из Джунгарии», встречающийся и в научных исследованиях, и в популярных публикациях, - «свидетельство моделирования собственной истории», представители определенной части современных калмыков вновь обращаются «к общему прошлому, «ревитализируя» ойратский период и общеойратскую идентичность, несмотря на вековые традиции этнического самосознания калмыков, принявших экзоэтноним в качестве самоназвания» [Бакаева 2017: 389].

Представления о прародине как Джунгарии встречались в калмыцком обществе и в прошлом, что определено, во-первых, известностью Джунгарского ханства, занимавшего значительные территории в Центральной Азии в период его расцвета, во-вторых, разными датировками появления термина. И в современных публикациях, и в общественном сознании широко распространено мнение, что калмыки - потомки средневековых ойратов Джунгарии. Это мнение отчасти основано на работе известного ученого Г. О. Авляева, который писал об откочевке части ойратов, предков калмыков, «из Джунгарии» [Авляев 2002: 114, 281], о том, что калмыки-торгоуты были «потомками средневековых калмыков-торгоутов Джунгарии» [Авляев 2002: 114], но вместе с тем, говоря об общем происхождении, перечислял: «калмыки Поволжья и ойраты Джунгарии и Кукунора» [Авляев 2002: 27]. Необходимо учитывать, что, согласно Г. О. Авляеву, термин зюнгар (или джунгар), который в различные периоды имел разное значение и прежде всего был связан с определением сторон света (и, соответственно, с флангами в военном деле), уже со второй половины $\mathrm{XV}$ в. приобрел этническое значение, «обо- значая племенную общность ,зюнгар“ во главе с ханским родом „цорос“. Позже этноним ,зюнгар“, или „джунгар“, приобрел собирательное значение, стал общим именем ойратов Джунгарского ханства (1636-1758) и названием страны (Джунгария)» [Авляев 2002: 115]. Но, как показал В. П. Санчиров, термин джунгары (монг., ойрат. зүҮн гар) в этническом смысле стал использоваться позже: по данным источника «История ХоУрлюка», этот этноним появился в 1637 в. как следствие построения ойратского войска в сражении с войском халхаского Цогтутайджи во время противостояния в Кукуноpe [Хо-Өрлөгийн түүх 2001: 165; История Хо-Ӧрлӧка 2016: 33-34; Санчиров 2013: 53]: так стали называть объединение ойратоволётов, которое занимало левый фланг во время битвы. В научной литературе отмечалось, что упоминание термина «зюнгар» как обозначения этнополитического объединения встречается в «ранний период» [Очиров 2008: 124] в «Сказании о поражении монголов в войне с ойратами» (известном в научной литературе под названием «История о монгольском Убаши-хунтайджи») [Лунный свет 2003: 41, 53], в котором повествуется о поражении монголов ойратами в 1587 г. Но текст этого памятника распространялся устным путем и был зафиксирован на ойратском (старокалмыцком) «ясном письме», созданном, как известно, в 1648 г., и потому мнение В. П. Санчирова о появлении этнонима зүүнгар (джунгар), основанное на тексте старописьменного памятника исторического характера, следует считать обоснованным.

Популярность тезиса о происхождении калмыков «из Джунгарии» можно проиллюстрировать на примере фильма об американских калмыках, снятого в США Норманом Макки в 1960-е гг. при поддержке активистов калмыцкой диаспоры и со специальными комментариями проф. Араша Борманжинова, который назывался «Americans from Jungaria / Американцы из Джунгарии» [Americans from Jungaria]. Авторы этого фильма, посвященного калмыкам Нью Джерси, писали в титрах: «Наша прародина находится в Джунгарии в северной части провинции Синьцзян. Сегодня, находясь за полмира от Джунгарии, в штате Нью Джерси, калмыки остаются буддистами-ламаистами и почитают Далай-ламу как своего духовного лидера. Более того, брат нынешнего Далай-ламы Норбу является почетным 
участником всех калмыцких обрядов, проводимых в Freewood Acres <...> с того как все начиналось в Джунгарии 300 лет назад $<\ldots>$ калмыки-монголы были кочевниками» [Americans from Jungaria]. Другой пример: в столице Калмыкии г. Элисте в 1970-е гг. детская площадка в парке «Дружба» была названа «Джунгарией».

В последние два десятилетия термин «Джунгария» приобрел особую популярность (в Москве зарегистрировано РОО «Калмыцкое землячество Джунгария» [Джунгария — больше ... 2012; РОО Джунгария], в социальных сетях появились группы, объединяющие калмыков-зюнгаров [Кто мы, ЗюнГары?], и др.), что можно рассматривать в контексте попыток конструирования современной этнической идентичности и формирования новых «мифологем», которые получают распространение в среде молодежи, с одной стороны, интересующейся историей своего народа, с другой недостаточно знакомой с ней. Так, несмотря на наличие признанной научной концепции, основанной на историческом анализе источников и отраженной в большом ряде научных трудов, в том числе в академической «Истории Калмыкии с древнейших времен до наших дней», в которой уже во введении конкретно указывается: «у калмыков общая с ойратами древняя и средневековая история, протекавшая на территории Центральной Азии» [История Калмыкии ... 2009, I: 8], через интернет-технологии отдельные общественные деятели, блогеры внедряют идею единой этнической идентичности калмыков и западных монголов (ойратов). К примеру: участники интернет-форума «Свободная Калмыкия», освещая подготовку в 2007 г. первой комплексной научной экспедиции калмыцких ученых в Западную Монголию, отмечали: «Экспедиция в Западную Монголию - вековая мечта калмыцких исследователей. Так как именно там компактно проживает около 270 тысяч ойратов, с которыми современные калмыки России являются одним народом» [Ученые готовят ... 2007]. С данной концепцией связано появление противоречащей историческим фактам идеи, согласно которой одно из трех ойратских государств, созданных в XVII в., являлось своеобразной «метрополией» для двух других, - идеи, которая тиражируется в некоторых интернет-публикациях и вводит пользователей интернета, ограничивающихся одним типом источников, в заблуж- дение в силу недостаточного знания ими истории. Примером может служить сайт mediaknowledge.ru, где в статье «Калмыки» (глава «Этногенез и этническая история») читаем: «Величайшая империя кочевников нового времени известна сейчас под названием Джунгарское ханство. Современная Калмыкия является фактически осколком этого государства. В 1698 г. во время правления хана Аюки произошел разрыв волжских калмыков с Джунгарией. Образовалось самостоятельное Калмыцкое ханство» [Калмыки]. Авторы процитированной публикации игнорируют факты (Джунгарское государство образовалось в 1635 г. [Златкин 1983: 98], Калмыцкое ханство складывалось в этот же период на отдаленных от него территориях, и завершение его формирования разные исследователи датируют от 1650-х до 1680-х гг. [Батмаев 2009: 344-352]) и последовательно проводят таким образом идею первенства Джунгарского ханства и второстепенного значения Калмыцкого ханства, что противоречит научной точке зрения [Батмаев 2009: 344-354; История Калмыкии 2009, I; Калмыки 2010; и др.].

И. Я. Златкин пишет по этому поводу: «В 1634 г. Хара-Хула умер, оставив своему сыну и преемнику Хото-Хоцин-Батуру пост второго (наряду с Байбагасом хошоутским) „первенствующего члена“ ойратского чулгана. Далай-лама пожаловал Батуру титул Эрдэни-Батур-хунтайджи. Фактически Батур-хунтайджи стал единовластным правителем всех ойратских кочевий, за исключением тех, которые вслед за Хо-Урлюком ушли на Волгу, где в это же примерно время началось создание другого ойратского ханства — Калмыцкого» [Златкин 1983: 98].

Отчасти заблуждению способствует обозначение термином Джунгария (основное его значение «Джунгарская равнина», находящаяся на севере китайского Синьцзяна) территории, откуда пришли ойратские этнические группы ${ }^{1}$, вошедшие в состав калмыцкой народности, — хотя этот топоним появился в период после ухода предков калмыков из Центральной Азии [Хо-Өрлөгийн түүх 2001: 165; История ХоӦрлӧка 2016: 33-34; Санчиров 2013: 53], а

${ }^{1}$ Несомненно, границы кочевий, где обитали предки калмыков - ойраты этнополитических объединений торгутов, дербетов, хошутов, охватывали гораздо большую территорию, нежели Джунгарская равнина - географическая и историческая область в СУАР КНР. 
условной датой добровольного вхождения калмыцкого народа в состав Российского государства принято считать 1609 г.

Таким образом, зачастую в популярных публикациях высказываются точки зрения, противоположные научным концепциям, согласно которым Джунгарское ханство, Хошутское ханство и Калмыцкое ханство были основаны в начале XVII в., а основное население этих государств принадлежало к разным этнополитическим объединениям. И вновь мы находим «основание» в некоторых цитатах из научных публикаций. В응 введении (подчеркнуто мной. - Э. Б.) к монографии Г. О. Авляева о происхождении калмыцкого народа читаем: «Калмыки Поволжья, Джунгарии и Северного Тибета (Куку-Нор, или Цинхай), Алашани, Эдзингола, Ганьсу-Нинься и т. д. являлись единым этносом, имевшим в конце XVI-XVIII вв. одновременно 3 государства: 1) Джунгарское, или Ойратское ханство в западной части бывшей Монгольской империи; 2) Хошоутовское ханство в Тибете; 3 ) Калмыцкое (или Торгоутовское) ханство в составе Российской империи» [Авляев 1994: 6; Авляев 2002: 7]. Но в самой монографии последовательно разделяются российские калмыки и ойраты Джунгарии и Кукунора. К тому же ученый на той же странице писал: «у калмыков Поволжья в связи со становлением Калмыцкого ханства на Волге начался новый этап в этнической истории - процесс консолидации всех групп ойратов XVII в. [торгоутов (основной компонент), дербетов и хошутов] в новую калмыцкую этническую общность [Авляев 2002: 7; примерно тот же текст в предыдущем издании: Авляев 1994: 6]. То есть, Г. О. Авляев считал, что средневековые ойраты представляли единый этнос, a c начала XVII в. происходила консолидации части их групп в новый, калмыцкий, этнос - о чем и свидетельствуют обширные материалы, приведенные в его монографии. Но эта точка зрения недостаточно четко сформулирована во введении к основной части значимого труда калмыцкого этнолога, проведшего большую и важную работу по собиранию полевых материалов, изучению разнообразных источников и их анализу, позволившему создать фундаментальное исследование о происхождении калмыцкого народа, значение которого трудно переоценить. Вполне вероятно, что неточная формулировка о «калмыках Поволжья, Джунгарии и Северного Тибета (Куку-Нор, или Цин- хай), Алашани, Эдзин-гола, Ганьсу-Нинься и т. д.» именно во введении обусловлена большим объемом работы, когда основное внимание ученого было сконцентрировано на основной части исследования, к которой и обращаются те, кто изучает этническую историю калмыков. И только читатели, не углубляющиеся в научный труд, могут тиражировать вырванные из контекста некоторые неточные фразы из научных текстов, которые ими воспринимаются за истину. Таким образом, опасность состоит в широкой публикации неточно сформулированных тезисов, не соответствующих научным выводам тех же ученых.

Другой вопрос, на который есть разные ответы, - время сложения калмыцкого народа. Все ученые сходятся во мнении, что первый, ранний этап этнической истории предков калмыков являлся общим с этапом формирования ойратских народов. Второй этап связан со сложением калмыцкого народа, и завершение его обычно датируется периодом правления хана Аюки и расцвета Калмыцкого ханства [Авляев 2002: 273-279; Батмаев 2002: 112]. Соответственно, завершая монографию о происхождении калмыцкого народа временем его окончательного формирования (периодом Аюки-хана) [Авляев 2002: 273-279], содержание следующего периода этнической истории Г. О. Авляев рассматривает как этноэволюционные процессы. М. М. Батмаев же относительно периода после откочевки большей части калмыков в 1771 г. на восток во главе с наместником ханства Убаши пишет о раздельном развитии двух частей одного этноса [Батмаев 2002: 112] — в Поволжье и в Центральной Азии.

Однако встречается мнение о том, что завершение формирования этноса следует датировать концом XVIII в. - временем после откочевки большей части народа в 1771 г. в Центральную Азию, в пределы разгромленной Цинской империей Джунгарии и, соответственно, трансформации субэтнической структуры. Особенно примечательными являются некоторые материалы СМИ, форумов в социальных сетях, в которых слышатся заявления о завершении формирования калмыцкой народности в современный период, к примеру: «До ХХ в. для калмыков было характерно наличие племенных группировок - дербетов, торгоутов, хошеутов и олётов (зюнгаров). На современном этапе происходит активное 
смешение родов и формирование единой калмыцкой нации» [Калмыки]. Так в популярных публикациях отражаются обыденные представления о состоянии этнической идентичности. Казалось, такие публикации коррелируются с современными концепциями конструктивизма («Идентичность, как самоопределение личности по отношению к другим, своим и чужим, представляет собой социальный конструкт» [Шахбанова 2013: 136]), - но терминология в вышеприведенном примере из интернет-ресурса указывает на примордиальное понимание этноса, и в этом аспекте в нем речь идет о том, что до $\mathrm{XX}$ в. и на протяжении его части калмыки не представляли собой самостоятельный сложившийся этнос.

Важно отметить: заявления, подобные вышеуказанным, не отрицают наличие калмыцкой идентичности в период до ХХ в. Так, на том же сайте, в той же статье «Калмыки» авторы пишут: «Как бы то ни было, первые упоминания о калмыках в русских источниках относятся к началу XVI века, времени царствования Елены Глинской $<\ldots>$ В XVII веке, в результате мощной экспансии, калмыки заняли громадные территории от Дона до Енисея по широте и от Урала до границ Индии по долготе» [Калмыки].

Казалось бы, проблема решена. Но далее читаем: «В 1640 году, на съезде калмыцких (ойратских) $)^{1}$ ханов в предгорьях Тарбагатайского горного хребта, был принят общекалмыцкий (ойратский) свод законов Ик Цааджн Бичг (традиционно переводится на русский как Великое Степное Уложение), который институализировал единое правовое пространство от Кавказа до границ Индии» [Калмыки].

Оставив в стороне вопрос о дискутируемости описываемых территориальных границ кочевий ойратов и калмыков, обратим внимание на распространенность представлений о единой идентичности не только калмыков с ойратами (что можно объяснить происхождением калмыков от ойратских этнических групп), но и ойратов с калмыками (причем не аргументированных). Можно предположить, что словосочетание общекалмыцкий (ойратский) основано на привычном слуху определении старокалмыцкая (ойратская) письменность, о котором знает каждый школьник Калмыкии.

\footnotetext{
${ }^{1}$ Подчеркнуто мной. — Э. Б.
}

Итак, несмотря на имеющиеся научные работы о происхождении калмыцкого народа, в обыденном сознании встречаются распространяемые некоторыми интернетресурсами представления о том, что единая идентичность калмыков могла сложиться в начале XX в. Каковы причины появления этой идеи? Несомненно, они заключаются в наличии свидетельств о бытовавшей в указанный период не только калмыцкой, но и иной идентификации. Но идет ли речь о процессе конструирования калмыцкой идентичности в первой трети ХХ в., подобном исследованному рядом ученых процессу «конструирования советских наций из разнородной этнической материи» [Тишков 2016а: 7]?

В связи с этим рассмотрим, как вопросы этнической идентификации отразились в документах калмыцких буддистов первой трети XX в. Обращение к этому типу источников обусловлено значимостью религии в сложносоставных обществах, к каковым относились в начале XX в. и Россия в целом, и Калмыкия. Как отмечает В. А. Тишков, главной проблемой и особенностью стран со сложным составом населения являются религиозные различия [Тишков 2016б: 18]. Государство (полития), по мнению В. А. Тишкова, - главная форма социальной группировки людей; в его управлении определенные сложности вызывают этнические и религиозные различия [Тишков 2016б: 18-23]. Поэтому большое значение при анализе форм идентичности в обществе приобретают изучение конфессиональной и этнической идентичностей.

Необходимо отметить, что вопросы этнической и религиозной идентичности в начале XX в. в Калмыкии приобрели особую актуальность, что было обусловлено целым рядом факторов. С конца XIX в. активизировались связи калмыцких буддистов с другими буддийскими центрами, и это было связано с несколькими причинами. Во-первых, Россия активизировала свою внешнюю политику в дальневосточном направлении в конце XIX в. Во-вторых, в русле этой политики налажены были российско-тибетские отношения, и именно в это время Тибет духовный центр - стал открываться миру [Россия и Тибет 2005: 14-32]. В-третьих, в силу сложившихся обстоятельств российские буддисты и некоторые крупные чиновники вынашивали планы переселения Далай-ламы в Россию [Россия и Тибет 2005: 
25; Бакаева 2005: 46-56]. Вместе с тем произошли разительные перемены в социальной жизни российского общества после революции 1905 г.; для калмыков-буддистов же появились возможности в осуществлении паломничеств в Тибет и открытия новых монастырских центров, а у оренбургских калмыков, считавшихся православными христианами, - и признания их буддистами [Джунджузов 2013]. Известный факт, что первым фотографом священной Лхасы, бывшей закрытой до того времени для иностранцев, стал калмык Овше Норзунов, свидетельствует об актуализации религиозной составляющей в калмыцком обществе начала XX в.

Из большого ряда документов, освещающих конфессиональную жизнь калмыцкого общества в начале XX в., обратим внимание на материалы съезда буддистов, на котором были представлены посланцы от всех территориально-административных единиц, где проживали калмыки: логично предположить, что специфика этнической идентичности могла отразиться в документах, охватывающих представителей разных этнических групп. Итак, в 1923 г. состоялся съезд буддийского духовенства, называвшийся в официальных документах Первым ${ }^{1}$ [НА РК. Ф. Р-3. Оп. 2. Д. 368].

Особая ситуация сложилась на духовном съезде в связи с вопросом о выборах Ламы калмыцкого народа, в должности которого с 1920 г. состоял Гава Сеперов (уроженец Вто-

1 Нумерация съездов в период с 1917 по 1925 гг., по данным архивных документов, весьма запутана. Известно, что в июле 1917 г. состоялся первый духовный съезд, до которого (в марте 1917 г. на I съезде представителей калмыцкого народа) имело место собрание большой группы духовенства во главе с Ч. Балдановым. В июле 1920 г. по окончании первого Общекалмыцкого съезда состоялся другой духовный съезд [НА РК. Ф. Р-3. Оп. 2. Ед. хр. 509. Л. 17об.]. Видимо, потому съезд духовенства 1923 г. называется в одних документах первым, в других четвертым. В 1925 г. состоялся духовный съезд, который называют то третьим, то пятым (в этом случае съезд 1923 г. называется четвертым, хотя в его документах он именуется первым). Таким образом, хотя в 1923 г. духовный съезд торжественно называли Первым, выяснилось, что на деле он являлся четвертым, а третьим в таком случае следует считать съезд, состоявшийся в 1920 г. по окончании 1-го Общекалмыцкого съезда [Бакаева 1997б]. рого Ики-Чоносовского аймака Большедербетовского улуса и в прошлом глава одного из хурулов Большедербетовского улуса ${ }^{2}$ ), представитель обновленческого движения.

В информационном отчете о съезде буддийского духовенства Калмыцкой автономной области представитель Наркомата по делам национальностей РСФСР и ответственный секретарь обкома партии И. Р. Марбуш-Степанов в связи с этим вопросом (о выборах ламы) отмечал, что в течение трех лет после выборов Г. Сеперова Ламой калмыцкого народа «шла глухая и непрерывная борьба <...> Старые бакши упорно сопротивлялись новому течению, стараясь удержать свое старое положение, и ожидали момента решительной схватки при выборах Ламы в нынешнем году на исходе трехлетия, где должен был утверждаться Устав буддийского духовенства, долженствующий окончательно утвердить позиции нового течения» [НА РК. Ф.Р-3. Оп. 2. Д. 509. Л. 17об.]. Таким образом, речь как будто шла о противостоянии старшего и молодого поколений ${ }^{3}$ по вопросу об обновленческом движении. В Протоколе духовного съезда отражено решение об избрании «Ламой калмыцкого народа дорамба Гава Сеперова из Большедербетовского улуса» Центрального Духовного Совета в составе «гелюнга Яндыковского улуса Гаря Овджаева, аринджанба Икицохуровского улуса Монти Базырова, гавджи Малодербетовского улуса Чемпель Баслиева» и ми-

${ }^{2}$ После ухода по болезни в 1924 г. с поста Ламы калмыцкого народа Гава Сеперов через два года становится старшим бакши хурулов Большедербетовского улуса и одновременно главой своего родового Ики-Чоносовского хурула [Манжикова 2003: 112]. В 1931 г. по «делу Тепкина и других» Г. Сеперов был осужден к 7 годам заключения [Бакаева 1997a: 4].

${ }^{3}$ Гава Сеперов, бывший Ламой калмыцкого народа в 1923 г., родился в 1884 г. [Манжикова 2003: 111], и ко времени съезда ему было только 39 лет. В предшествующие периоды лица, занимавшие эту должность, обычно были в более солидном возрасте. Так, Лама калмыцкого народа в 1898-1906 гг. Джимбе Балдан Делгеркиев был назначен на этот пост, будучи в преклонном возрасте - в 83 года [Бакаева 2001: 312-324]. Чимид Балданов, Лама калмыцкого народа в 1907-1920 гг., духовное звание получил 24 мая 1864 г. [НА РК. Ф. И-9. Оп. 1. Ед.хр. 414. Л. 116], впоследствии являлся бакши Цаган-Аманского хурула. 
рян - М. Намруева из Манычского улуса, У. Лиджиева из Икицохуровского улуса, Б. Шоваева из Багацохуровского улуса [НА РК. Ф. Р-3. Оп. 2. Д. 509. Л. 13об.], ревкомиссии в составе гелюнга Манычского улуса Аравга Насанкиева, мирян У. Норзунова ${ }^{1}$ из Большедербетовского улуса, Б. Кензеева из Манычского улуса [НА РК. Ф.Р-3. Оп.2. Д. 509. Л. 13об.]. Но представитель Наркомнаца И. Р. Марбуш-Степанов, наблюдавший за ходом съезда, сообщал, что имела место «попытка организовать раскол < ...> со стороны представителей духовенства торгоутовцев (торгоутовцы - это племенное деление калмыков, к которому относятся калмыки Яндыко-Эркетеневского и Икицохуровского улусов). Торгоутовцы устроили свое собрание и выдвигали кандидатуру Ламы - Ламу донских калмыков ${ }^{2}$, который является скорее сторонником старого течения, чем обновленческого. Но почему-то на Пленарном заседании съезда во время выборов торгоутовцы своего кандидата не выдвинули, и таким образом почти единогласно прошла кандидатура Сеперова» [НА РК. Ф.Р-3. Оп. 2. Д. 509. Л.20]. Таким образом, речь шла о разногласиях в среде духовенства. Этим можно объяснить то, что в преддверии духовного съезда состоялось предварительное совещание, на котором присутствовали хамбо-лама Агван Доржиев, Лама калмыцкого народа Гава Сеперов, заместитель представителя тибетского правительства при РСФСР Лувсан Шараб Тепкин, старшие бакши Большедербетовского, Малодербетовского улусов и Лама донских калмыков [НА РК. Ф.Р-3. Оп. 2. Д. 509. Л. 18-18об.], и не было представителей духовенства из других улусов, впоследствии устроивших свое собрание. В данной связи отметим, что монахи, занимавшие должность Ламы калмыцкого народа в предшествующий период, являлись выходцами из Багацохуровского улуса, где основное население составляли калмыки-торгуты ${ }^{3}$. Так, Боро Шара Манджиев до назначения на должность Ламы калмыцкого народа (1887-1897) являлся

${ }^{1}$ Речь идет об Овше Норзунове, в документах съезда названного Убуши Норзуновым.

${ }^{2}$ С 1920 по 1926 гг. Ламой донских калмыков был Иван Китанов (духовное имя Гаванг Араш, годы жизни: 1859-1926) [Борманджинов 1997: 27].

${ }^{3}$ В старой литературе и архивных источниках термин торгуты зачастую пишется в форме торгоуты. улусным бакши Багацохуровского улуса, Джимбе Балдан Делгеркиев до избрания Ламой калмыцкого народа (1898-1906) являлся улусным бакши Александро-Багацохуровского улуса, Чимид Балданов (Лама калмыцкого народа в 1907-1920 гг.) еще в 1898 г. являлся бакши Докшадын хурула Багацохуровского улуса, затем занял должность, которую занимал ранее Д. Б. Делгеркиев [Бакаева 2001: 312-324]. Таким образом, с прежним руководством буддийской церкви была связана позиция консервативного крыла калмыцкого духовенства, которое формировалось вокруг «старых бакши», «упорно сопротивлявшихся новому течению» [НА РК. Ф.Р-3. Оп. 2. Д. 509. Л. 17об.], и такая позиция была определена еще со времен Ламы калмыцкого народа Джимбе Балдана Делгеркиева (1898-1906) и его преемника Чимида Балданова (1907-1920), на которого престарелый лама неоднократно перекладывал свои полномочия и который исполнял эти обязанности в последние годы до своего официального избрания [НА РК. Ф.И-9. ОП. 5. Д. 953. Л. 30-49] - вероятно, именно Ч. Балданов в ответ на обращение А. Доржиева об открытии школ цаннита «не дал разрешения основать новые монастыри в калмыцких районах торгутов и дурбетов. Большинство старых лам сказали: „Новая религия, которая не распространялась раньше, не подойдет людям, живущим в юртах“» [Доржиев 1994: 57], о чем в автобиографии хамбо-ламы говорится: «Когда в калмыцких землях на реке Едзил [я] учредил первый чойра, главенствующий Шашин-лама стал чинить всяческие препоны, говоря, что, мол, нельзя создавать цанит-Чееря там, где нет чееря, установленного издавна. Это не годится для народа, живущего под войлочными потолками. Но у меня появились союзники в лице князя Цэрэндая и других. В [улусах] Бага-Дэрбэт и Ихэ-цохор учредили два чееря» [Доржиев 2003: 54].

В рассмотренных документах калмыцких буддистов отражены не только противостояние консервативной и обновленческой частей духовенства, но и связь различных группировок с разными этнотерриториальными объединениями калмыков, что обусловлено известной традицией: в конфессиональной среде у калмыков, как и у родственных им народов, тесная связь буддийских монастырей с родовой структурой общества [см.: Бакаева, Орлова, Хишигт, Энхчимэг 2015] сохранялась до первой трети ХХ в. 
Так, в 1924-1926 гг. в Калмыцкой автономной области проводилась регистрация религиозных обществ. Согласно «Книге регистрации ${ }^{1} »$, были зафиксированы следующее религиозные общества калмыков-буддистов:

- буддийское религиозное общество Калмбазара, подчинявшееся ЦДС буддистов Калмыцкой области;

- религиозное общество Багацохуровского хурула Багацохуровского аймака Калмбазаринского улуса;

- в Яндыко-Мочажном улусе: Батутовское буддийское общество в ур. Хаптха, религиозные общества Таджинского хурула, Харахусовского хурула, Шарнутовского аймачного хурула, Шарс-Багутовского малого хурула, Аршинского хурула хотона № 1 Батутовского аймака, Шебенерского хурула Долбанского аймака, Геленгякинского хурула Долбанского аймака, Гахатинского Большого хурула Долбанского аймака, Гендинского малого хурула Долбанского аймака; общество при малом Бенбетском ${ }^{2}$ хуруле Долбанского аймака, религиозное общество Долбанского аймака, Багацатановское аймачное общество, Ики-Багутовское аймачное общество, буддийские общества Дойда-Багутовского аймака, Актюбеевского аймака, Долбанского аймака, Хамхутинского сельского общества Багацатановского аймака, общество при малом Замутовском хуруле Долбанского аймака, Степно-Багутовское общество Долбанского аймака, Замутовское общество Багацохуровского аймака;

- в Багащохуровском улусе: религиозное общество Зюневского аймака;

- в Хошеутовском улусе: общество Джакуевского хурула;

- в Икицохуровском улусе: религиозные общества Хошеутовского хурула, Зюнгаровского хурула, Ачинеровского хурула, Эркетеновского хурула, буддийские общества Яшкульского аймака, Сатхаловского аймака, Кетченер-Шебенеровского аймака, Дерямин Бакшин Гунджан Шебенеровское общество Кетченер-Шебенеровского аймака, Тохан Кесикова, Эмчин Шебенеровского хурула общество Кетченер-Шебенеровского аймака;

${ }^{1}$ Ниже приводятся названия религиозных буддийских обществ так, как они зафиксированы в архивном деле [НА РК. Ф. Р-3. Оп. 2. Д. 508а. 196 л.].

2 Так в источнике. - Э. Б.
- в Эркетеновском улусе: общество Центрального хурула, Южного хурула, Северного хурула;

- в Малодербетовском улусе: буддийские религиозные общества Центрального аймака на ур. Ханата, Шарнутовского аймачного хурула, Бага-хурульского аймака, Шебенеровского аймака, Сталинского аймака, Сальского аймака, общество Цаганнурского аймака и Сарлакиновское общество этого аймака, Бакшин-Шебенеровское общество Шебенеровского аймака;

- в Манычском улусе - Джеджекиновское, Кебютовское, Ульдючиновское, Манджекиновское буддийские общества, религиозные общества Бурульского хурула Джанчибакиновского хотона, Оргакинского хурула, Ленинского хурула, Багачоносовского хурула, общества Багабурульского хотона Бурульского аймака, Келькет-Наинтакиновское общество, религиозное общество Абганеровского аймака, общество Богдахинского хотона Оргакиновского аймака;

- в Большедербетовском улусе: религиозные общества 1-го и 2-го Икичоносовских, Хаджикинского и Будульчинеровского аймаков, 1-го и 2-го Икитуктуновских аймаков, Бюдермис-Кебютовского аймака Цоросской волости, Багабурульского аймака, религиозное общество 2-го Икичоносовского (Раши Гемпель) хурула, Объединенное общество буддистов из донских переселенческих хотонов (Ново-Бурульского, Степного, Бижинского, Бемдякинского, Сладковского, Амурсананского) [НА РК. Ф. Р-3. Оп. 2. Д. 508а. Л. 1-23об.].

В 1930 г. вновь проводилась регистрация религиозных обществ, названных при их фиксации объединениями или общинами. Среди буддийских объединений Калмыцкой автономной области, перечисленных в книге регистрации, вновь звучат названия родов и аймаков калмыков: общины шарс-багутовская, ики-багутовская, дойдабагутовская, шебенеровская, хахачинская, геленгякинская, гахатинская, генденская, тайджинская (Яндыко-Мочажный улус), манджекинская, джеджекинская, багачоносовская, оргакинская, кебютовская, багабурульская (Манычский улус), зюнгарская, эркетеневская, сатхаловская, багацатанская, алягутская, бакшин-хурульская (Икицохуровский улус), баруновская, авинкинская, асмют-хапчинская, икихурульская, багахурульская, ханатинская, догзмакинская (Ма- 


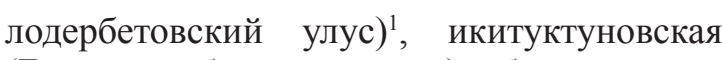
(Большедербетовский улус), абганеровская, икичоносовская (Западный улус), харахусовская, долбано-замутовская, замутовская, батутовская, эрдниевская, багацатановская, степно-багутовская (Приморский улус ${ }^{2}$ ), джанчибакиновская, келькетовская, наинтанкиновская, икичоносовская (Центральный улус $\left.{ }^{3}\right)$, икибухусовская, багабухусовская (Сарпинский улус) ${ }^{4}$ [НА РК. Ф.Р-3. Оп.2. Д. 508а. Л. 26-43об.].

Необходимо учитывать, что в первые десятилетия XX в. в Калмыцкой степи, несмотря на постоянно происходившее сокращение кочевий, в целом сохранялось сложившееся в течение столетий компактное проживание разных субэтнических групп калмыков. Так, в 1920-1921 гг. А. М. Позднеев отмечал, что в начале века Калмыцкая степь Астраханской губернии включала три основные части: 1) юго-восточная (приморская, Мочаги) часть занимала 700000 десятин, 2) западная (гористая, Ергени) 2128352 десятины, 3) остальная часть занимала 4200000 десятин [АВ ИВР РАН. Ф. 44. Оп. 1. Д. 56. Л. 26]: «В течение двух веков племена и поземельные отношения колебались и изменялись, пока не определились, наконец, устойчивые группы, постоянность которым придала администрация, оформив их административными актами и системой управления [АВ ИВР РАН. Ф. 44. Оп. 1. Д. 56. Л. 37]. Таким образом, население Малодербетовского улуса составляли дербеты, население Багацохуровского, Харахусо-Эрдениевского, Икицохуровского, Яндыковского, Эркетеневского - торгуты и отчасти зюнгары и хойты в Икицохуровском улусе, население Хошеутовского

${ }^{1}$ В Малодербетовском улусе также были зарегистрированы сальская и кегультинская общины, названные по наименованию аймака и населенного пункта.

${ }^{2}$ В Приморском улусе также были зарегистрированы северная, южная, центральная, промысловская религиозные буддийские общины.

${ }^{3}$ В Центральном улусе также была зарегистрирована яшкульская буддийская община.

${ }^{4}$ В 1930 г. были зарегистрированы и джакуевская буддийская община в Приволжском улусе, буддийская община Хошеутовского улуса, а также религиозные общины, относящиеся к иным конфессиям: православные общины, баптистская, лютеранская общины, община евангельских христиан, иудейская община [НА РК. Ф. Р-3. Оп. 2. Д. 508а. Л. 26-43об.].
(Александровского) улуса являлось хойтами с значительной примесью торгутов, а Мочажный улус представлял собой «конгломерат всех племен и улусов» [АВ ИВР РАН. Ф. 44. ОП. 1. Д. 56. Л. 37]. Дербеты занимали Ергени, хошеуты - заволжские степи, часть центральной степи, прибрежную к Волге, торгуты - центральную степь, где выделялись пять неравных частей (северовосток - Багацохуровский улус, центр Харахусо-Эрдениевский улус, юго-восток - Яндыковский улус, юго-запад - Эркетеневский улус), хойты и зюнгары - северозападную часть центральной степи.

А. М. Позднеев выделил в административном делении Калмыцкой степи 10 частей: Малодербетовский улус (включая северную и южную части), Багацохуровский улус (включая также две части - собственно Багацохуровский улус и Александровский (Хошеутовский) улус), Яндыко-Икицохуровский улус (включая две части - Яндыковский и Икицохуровский улусы), Харахусо-Эрдениевский улус, Эркетеневский улус, Мочажный улус, Калмбазар [АВ ИВР РАН. Ф. 44. ОП. 1. Ед. хр. 56. Л. 38].

Приведенные выше материалы регистрации религиозных общин в 1924-1926 гг. и в 1930 г. свидетельствуют о том, что в этот период в документах калмыцких буддистов, кроме названий традиционных субэтнических делений, которые совпадали до начала $\mathrm{XX}$ в. с наименованиями административнотерриториальных единиц, появляются иные названия религиозных общин, в которых отражено новое административное деление Калмыцкой автономной области. Вместе с тем, эти данные позволяют сделать вывод о сохранности иерархичного этнического самосознания калмыков: названия родов и аймачных объединений, зачастую именованных по этническим группам, являлись определяющими для объединений по конфессиональному признаку.

В связи с этим зафиксированное в материалах, которые относятся к духовному съезду калмыцких буддистов 1923 г., разделение его участников на «торгоутовцев» [НА РК. Ф.Р-3. Оп. 2. Д. 509. Л. 20] и на представителей калмыков-дербетов и донских калмыков можно рассматривать как свидетельство сохранности субэтнической идентичности - наряду с общекалмыцкой идентичностью. Весьма важным моментом является следующее: конфессиональная идентичность осмыслялась через иерархию 
этнических идентичностей и способствовала «закреплению» последней.

Таким образом, распространяемые некоторыми интернет-ресурсами представления о том, что единая идентичность калмыков могла сложиться в начале XX в., основываются на том, что в самосознании калмыков до этого периода сохранялись субэтнические подразделения и многоуровневая идентичность.

Как отмечает Л. М. Дробижева, «Этническое самосознание - это „образ мы“, т. е. и этнические стереотипы, и представление о происхождении, историческом прошлом своего народа, о языке, о культуре, территории проживания, и, что принципиально важно, мы включаем в этническое самосознание этнические интересы, то есть осознаваемые людьми потребности своего народа» [Дробижева 1991: 19]. В данном аспекте весьма значимым является осознание не только общего «образа народа», «образа мы», но и общие представления о своем происхождении и этнические интересы.

Поскольку этническая идентичность может быть подвержена трансформациям, важным моментом является осознание непротиворечивости многоуровневой идентификации.

Этническая и этнографическая гетерогенность учеными зафиксирована на различных этапах у разных народов. Такая характеристика была свойственна, по мнению Л. И. Шерстовой, для алтайцев [Шерстова 2006: 375], у которых, по мнению исследователя, признаки сформировавшейся однородной этнической группы прослеживались к началу XX в., когда в шести «дючинах» наблюдалась этническая однородность [Шерстова 2006: 390-391].

В среде же современных алтайцев наблюдаются объединительные и разъединительные (когда субэтнические группы признаются коренными малыми народами) этнические процессы. Анализируя эти разнонаправленные этнические процессы у алтайцев, А. П. Чемчиева приходит к выводу, что они «являются частью процесса самоопределения алтайских субэтносов» и «политическое и этническое самоопределение алтайских субэтносов не были тождественны друг другу», потому «многие представители алтайских субэтнических групп, обладая политической идентичностью коренного малочисленного народа, продолжают считать себя частью как своей этнической группы, так и алтайского этноса в целом» [Чемчиева 2017: 135].

У калмыков, консолидировавшихся в единую этническую общность уже в период Калмыцкого ханства, как можно видеть в документах начала и первой трети XX в., наряду с общепризнанным этнонимом, общей территорией, культурой и представлениями об общности родины и истории, сохранялись этнические деления и этнографические специфические характеристики, которые были зафиксированы позднее исследователями [Эрдниев 1970; Авляев 1994, 2002; и др.] и позволили реконструировать этнический состав калмыков вплоть до мелких подгрупп типа арванов [Басангова 2008; Батыров 2015; Генеалогия 2011; Шантаев 2009a, 2009б; Шараева 2003, 2007а, 2007б, 2008, 2009; и др.]. М. М. Батмаев считает, что в период сложения калмыцкой народности «через принадлежность к своему субэтносу и только вместе с ним они признавали себя калмыками» [Батмаев 2002: 118].

Представления об этнической идентичности, отражающие общность культуры и происхождения, и территориальных группах, которые существовали в калмыцкой степи до первой трети XX в., укреплялись или подтверждались в многоуровневой идентификации в конфессиональном сознании, которая реализовалась во взаимосвязи сети буддийских монастырей и иерархичной структуры общества. Именно со своим родовым или аймачным буддийским монастырем или храмом связывалась конфессиональная принадлежность, и в начале 1920-х гг. вопрос о сокращении буддийских храмов и общин являлся весьма болезненным, что выразилось в решениях об объединении буддийских приходов по аймакам.

Вместе с буддийской конфессиональной идентичностью значимой оставалась также субэтническая. В качестве примечательного свидетельства о том, насколько значимым являлось знание субэтнической идентичности не только калмыка-мирянина, но и священнослужителя, можно упомянуть приводимые Э.-Б. М. Гучиновой воспоминания калмыков-эмигрантов: «В Болгарии вначале не было священников. Но көгшн багши 1 (старый священник) приехал из Сербии,

${ }^{1}$ Написание слова зависит от контекста: в русском тексте - бакши, в калмыцком - багши. - Прим. в тексте книги Э.-Б. М. Гучиновой. 
увидел, что у нас никого нет, и прислал нам молодого бакши, родом Зюнгара» [Гучинова 2004: 49].

Таким образом, в конфессиональной сфере сохранялись и сигнифицировались через фиксацию этнонимов различия этнических групп калмыков. Стратифицированная этническая идентичность, отразившаяся в документах калмыков-буддистов первой трети XX в., свидетельствует как о сохранности границ этнических групп в пространстве, определенных спецификой административно-территориального деления, так и о выполнении ею функций этнических ментальных (духовных) маркеров. С этим в современной Калмыкии связаны поиски новых ментальных маркеров, определяющие обращение к раннему ойратскому и даже общемонгольскому периоду этнической истории. В рамках таких поисков в наши дни наблюдается актуализация термина Джунгария, которым зачастую обозначается в интернет-публикациях прародина калмыков (в то время как в среде западных монголов это понятие обозначается как «ойратский нутук») — этот факт можно отнести к категории «политических мифов, создаваемых и используемых культурными элитами» [Тишков]. В современном калмыцком обществе также прослеживается возрастающий интерес к истории родов. В то же время процессы, происходившие в XX в., привели к современному пониманию конфессиональной буддийской идентичности вне этнических делений калмыков.

\section{ИСТОЧНИКИ / SOURCES}

НА РК - Национальный архив Республики Калмыкия. [Natsional'nyy arkhiv Respubliki Kalmykiya [National Archive of the Republic of Kalmykia]. (In Rus.)]

АВ ИВР РАН - Позднеев A.M. Материалы к лекциям // Архив востоковедов Института восточных рукописей РАН. Ф. 44. Оп. 1. Ед. хр. 56. 1920-1921 гг. 72 л. [Pozdneev A.M. Materialy $k$ lektsiyam [Lecture reference materials]. // Arkhiv vostokovedov Instituta vostochnykh rukopisey RAN [Archive of Orientalists at the Institute of Oriental Studies of the RAS]. F.44. Op.1. Arch. unit 56. 1920 1921. 72 p. (In Rus.)]

Доржиев 1994 - Доржиев А. «Предание о кругосветном путешествии» или повествование о жизни Агвана Доржиева. Улан-Удэ: [б. и.], 1994. 119 с. [Dorzhiev A. «Predanie o krugosvetnom puteshestvii» ili povestvovanie o zhizni Agvana Dorzhieva [A tale about the 'world tour', or a narrative about Ven. Agvan Dorzhiev’s life]. Ulan-Ude, 1994. 119 p. (In Rus.)]

Доржиев 2003 - Доржиев А. Занимательные заметки: Описание путешествия вокруг света (Автобиография) / Агван Доржиев; пер. с монг. А. Д. Цендиной; транслит., предисл, коммент., глоссарий и указ. А. Г. Сазыкина и А. Д. Цендиной. М.: Вост. лит., 2003. 160 с. [Dorzhiev A. Zanimatel'nye zametki: Opisanie puteshestviya vokrug sveta (Avtobiografiya) [Entertaining notes: a description of the (author's) world tour (autobiography)]. A. D. Tsendina (transl.); A. G. Sazykin, A. D. Tsendina (translit., foreword, glossary, etc.). Moscow: Vost. Lit., 2003. 160 p. (In Rus.)]

Лунный свет 2003 - Лунный свет: Калмыцкие историко-литературные памятники: Пер. с калм. / сост., ред., вступ. ст., предисл., коммент. А. В. Бадмаева. Элиста: Калм. кн. изд-во, 2003. 477 с. [Lunnyy svet: Kalmytskie istoriko-literaturnye pamyatniki [The Moonlight: Kalmyk historical and literary monuments]. A. V. Badmaev (ed., comment., transl., etc.). Elista: Kalm. Book Publ., 2003. 477 p. (In Rus.)]

Россия и Тибет 2005 - Россия и Тибет: сб. pус. арх. док., 1900-1914. М.: Вост. лит., 2005. 231 c. [Rossiya $i$ Tibet: sb. rus. arkh. dok., 1900-1914 [Russia and Tibet: collected archival documents. 1900-1914]. Moscow: Vost. Lit., 2005. 231 p. (In Rus.)]

Хо-Өрлөгийн түүх 2001 - Хо-Өрлөгийн түүх // Ойрад Монголын түүхэнд холбогдох сурвалж бичгүҮд-ІІ. / Эмхтгэж, тод болон худам монгол бичгээс кирил бичигт буулган, тайлбар хийсэн На. Сухбаатар Улаанбаатар: Монгол улсын их сургууль, 2001. С. 157-166. [История Хо-Ӧрлӧка // Письменные источники по истории ойратовII. Сост., переложение со старомонг. и ойрат. письменности на кириллицу, комментарии На. Сухбаатара. Улан-Батор: Монгольский гос. ун-т, 2001. С. 157-166. На монг. яз.] [A History of Kho Orluk. Oyrad Mongolyn tüükhend kholbogdokh survalzh bichgü̈̈d-II [Written sources on the history of Oirats - (vol.) II]. Na. Sukhbaatar (translit., transl., comment., etc.). Ulaanbaatar: National Univ. of Mongolia, 2001. Pp. 157-166. (In Mong.)]

История Хо-Ӧрлӧка 2016 - История Хо-Ӧрлӧка // Письменные памятники по истории ойратов XVII-XVIII веков: сборник / сост., перев. со старописьм. монг., транслит. и коммент. В. П. Санчирова. Элиста: КИГИ PAH, 2016. C. 13-48. [A History of Kho Orluk. 
Pis 'mennye pamyatniki po istorii oyratov XVIIXVIII vekov: sbornik [Some $17^{\text {th }}-18^{\text {th }}$ written monuments on the history of Oirats: collected works]. Sanchirov V. P. (Comp., translit., transl., etc.). Elista: Kalmyk Humanities Research Institute, 2016. Pp. 13-48. (In Rus.)]

\section{ЛИТЕРАТУРА / REFERENCES}

Авляев 1994 - Авляев Г. О. Происхождение калмыцкого народа (середина IX - I четверть XVIII в.). М.; Элиста: Этнолог-центр, 1994. 250 c. [Avlyaev G. O. Proiskhozhdenie kalmytskogo naroda (seredina IX - I chetvert' XVIII v.) [The origins of the Kalmyk people (mid-9 $9^{\text {th }}-$ early $18^{\text {th }}$ cc.) $]$. Moscow; Elista: Etnolog-tsentr, 1994. 250 p. (In Rus.)]

Авляев 2002 - Авляев Г. О. Происхождение калмыцкого народа. Элиста: Калм. кн. издво, 2002.328 c. [Avlyaev G. O. Proiskhozhdenie kalmytskogo naroda [The origins of the Kalmyk people]. Elista: Kalm. Book Publ., 2002. 328 p. (In Rus.)]

Бакаева 1997a - Бакаева Э. П. Из истории процесса над буддийским церковным руководством: «Дело Тепкина и других»// VII Международный конгресс монголоведов (г. Улан-Батор, август 1997 г.). Доклады российской делегации. М.: ИВ РАН, ИЯ РАН, Общество монголоведов РАН, 1997. C. 3-5. [Bakaeva E. P. Excerpts from the trial of senior Buddhist clerical executives: 'The case of Tepkin and others'. VII Mezhdunarodnyy kongress mongolovedov $\left[7^{\text {th }}\right.$ Internat. Congress of Mongolists] (Ulaanbaatar, August 1997). Reports of Russian scholars. Moscow: Institute of Oriental Studies of RAS, Institute of Linguistics of RAS, Society of Mongolists (RAS), 1997. Pp. 3-5. (In Rus.)]

Бакаева 19976 - Бакаева Э. П. Лувсан Шараб Тепкин и его время / Шамбала. 1997. № 5-6. C. 9-17. [Bakaeva E. P. Luvsan Sharab Tepkin and his time. Shambala. 1997. No. 5-6. Pp. 9-17. (In Rus.)]

Бакаева 2001 - Бакаева Э. П. Ламы Калмыцкого народа (шаджин-ламы): процедура избрания // // Российское монголоведение. Бюллетень V. М.: Институт востоковедения PAH, 2001. C. 312-324. [Bakaeva E. P. Lamas of the Kalmyk people (Shajin Lamas): election procedures. Rossiyskoe mongolovedenie. Is. V. Moscow: Institute of Oriental Studies of RAS, 2001. Pp. 312-324. (In Rus.)]

Бакаева 2005 - Бакаева Э. П. СанктПетербургский храм: Агван Доржиев и калмыки // Буддийская традиция: история и современность. Юбилейные чтения, по- священные 150-летию со дня рождения Агвана Лобсана Доржиева. Материалы конференции. 25-24 ноября 2004 г. СПб.: ЭГО, 2005. C. 46-56. [Bakaeva E. P. The Buddhist temple of St. Petersburg: Ven. Agvan Dorzhiev and the Kalmyks. Buddiyskaya traditsiya: istoriya i sovremennost' [The Buddhist tradition: history and contemporaneity]. Jubilee readings to celebrate the $150^{\text {th }}$ anniversary of birth of Ven. Agvan Lobsan Dorzhiev. Conf. proc. 25-24 November 2004. St. Petersburg: EGO, 2005. Pp. 46-56. (In Rus.)]

Бакаева 2017 - Бакаева Э. П. «Джунгария далекая и близкая...» (к проблеме конкретноисторического изучения термина) // ХІІ Конгресс антропологов и этнологов России: сб. материалов (г. Ижевск, 3-6 июля 2017 г.). / отв. ред.: А. Е. Загребин, М. Ю. Мартынова. М.; Ижевск: ИЭА РАН, УИИЯЛ УрО РАН, 2017. С. 389. [Bakaeva E. P. 'Dzungaria - a land so remote, and so close ...' (revisiting the issue of specific historical research of the term). XII Kongress antropologov $i$ etnologov Rossii $\left[12^{\text {th }}\right.$ Congress of Russian Anthropologists and Ethnologists]. Collected papers (Izhevsk, 3-6 July 2017). A. E. Zagrebin, M. Yu. Martynova (eds.). Moscow; Izhevsk: Inst. of Ethnology and Anthropology of RAS, Udmurt Institute of History, Language and Literature (Uralic Branch) of RAS, 2017. P. 389. (In Rus.)]

Бакаева, Орлова, Хишигт, Энхчимэг $2015-Б а$ каева Э. П., Орлова К. В., Хишигт Н., Энхчимэг Ц. Буддийская традиция в Калмыкии и Западной Монголии: сакральные объекты. М.: Наука, Вост. лит., 2015. 238 с. [Bakaeva E. P., Orlova K. V., Khishigt N., Enkhchimeg Ts. Buddiyskaya traditsiya v Kalmykii i Zapadnoy Mongolii: sakral'nye ob"ekty [The Buddhist tradition in Kalmykia and Western Mongolia: sacral objects]. Moscow: Nauka, Vost. Lit., 2015. 238 p. (In Rus.)]

Басангова 2008 - Басангова Т. Г. Из истории арвана «мааткуд» // Проблемы этногенеза и этнической культуры тюрко-монгольских народов: сб. науч. статей. Вып. 2. Элиста: Изд-во КГУ, 2008. С. 110-111. [Basangova T. G. Excerpts from the history of the Maatkud arvan ('a paternal clan or its branch to constitute a combat unit of ten soldiers'). Problemy etnogeneza $i$ etnicheskoy kul'tury tyurkomongol'skikh narodov [The Turco-Mongols: challenges of ethnogenetic and ethnocultural studies]. Collected scholarly papers. Is. 2. Elista: Kalmyk State Univ., 2008. Pp. 110-111. (In Rus.)] 
Батмаев 2002 - Батмаев М. М. Социальнополитический строй и хозяйство калмыков в XVII-XVIII вв. Элиста: АПП «Джангар», 2002. 400 c. [Batmaev M. M. Sotsial'nopoliticheskiy stroy $i$ khozyaystvo kalmykov $v X V I I-X V I I I v v$. [Kalmyks in the $17^{\text {th }}-18^{\text {th }}$ cc.: socio-political and economic framework]. Elista: Dzhangar, 2002. 400 p. (In Rus.)]

Батмаев 2009 - Батмаев М. М. Образование Калмыцкого ханства // История Калмыкии с древнейших времен до наших дней. Т. 1. Элиста: Издат. дом «Герел», 2009.С. 344354. [Batmaev M. M. Foundation of the Kalmyk Khanate. Istoriya Kalmykii $s$ drevneyshikh vremen do nashikh dney [History of Kalmykia from the earliest times to the present days]. Vol. 1. Elista: Gerel, 2009. Pp. 344-354. (In Rus.)]

Батыров 2015 - Батыров В. В. К вопросу об истории арвана замлахн ульдючиновского рода Манычского улуса Калмыцкой степи в конце XIX - начале XX в. // Проблемы этнической истории и культуры тюркомонгольских народов. Элиста: КИГИ РАН, 2015. C. 318-325. [Batyrov V. V. Revisiting the history of the Zamlakhn arvan of the Uldyuchin clan (association) residing in Manych District of the Kalmyk Steppe: late $19^{\text {th }}$ - early $20^{\text {th }} \mathrm{cc}$. Problemy etnicheskoy istorii i kul'tury tyurkomongol'skikh narodov [The Turco-Mongols: problems of ethnic history and culture]. Elista: Kalmyk Humanities Research Institute, 2015. Pp. 318-325. (In Rus.)]

Борманджинов 1997 - Борманджинов А. Ламы калмыцкого народа: Ламы донских калмыков. Элиста: ЗелО; Зареалье, 1997. 60 с., илл. [Bormandzhinov A. Lamy kalmytskogo naroda: Lamy donskikh kalmykov [Lamas of the Kalmyk people: Lamas of the Don Kalmyks]. Elista: ZelO; Zareal'e, 1997. 60 p. (In Rus.)]

Генеалогия 2011- Генеалогия икицохуровских хошутов (по материалам, собранным Ш. В. Боктаевым) / сост. Б. Б. Манджиева. Элиста: КИГИ РАН, 2011. 326 с. (серия «Өвкнрин зөөр»). [Genealogiya ikitsokhurovskikh khoshutov (po materialam, sobrannym Sh. V. Boktaevym) [Genealogical tables of Iki Tsokhor Khoshuts (coll. by Sh. B.Boktaev)]. B. B. Mandzhieva (comp.). Elista: Kalmyk Humanities Research Institute of RAS, 2011. 326 p. (series 'Övknrin Zöör' / 'Heritage of Ancestors'.) (In Rus.)]

Гучинова 2004 - Гучинова Э.-Б. М. Улица «Kalmyk Road». История, культура и идентичности в калмыцкой общине США. СПб.: Алетейя, 2004. 340 с. [Guchinova E.-
B. M. Ulitsa “Kalmyk Road”. Istoriya, kul'tura $i$ identichnosti $v$ kalmytskoy obshchine SShA [Kalmyk Road. History, culture and identity of Kalmyks in the U.S.A.]. St. Petersburg: Aleteya, 2004, 340 p. (In Rus.)]

Дробижева 1991 - Дробижева Л. М. Этническое и историческое самосознание народов СССР на рубеже последнего десятилетия XX в. (в конце 60-х - нач. 90-х гг.) // Духовная культура и этническое самосознание. Вып. II. М.: Институт этнологии и антропологии, 1991. С. 16-38. [Drobizheva L. M. Peoples of the USSR at the turn of the 1960s1990s: current and historical ethnic self-designations. Dukhovnaya kul'tura i etnicheskoe samosoznanie. Is. II. Moscow: Inst. of Ethnology and Anthropology, 1991. Pp. 16-38. (In Rus.)]

Джунджузов 2013 - Джунджузов C. В. Легализация буддизма в Оренбургском казачьем войске (1906-1917 гг.) // Научные ведомости БелГУ. Серия История. Политология. Экономика. Информатика. 2013. № 22 (165). Вып. 28. C. 121-127. [Dzhundzhuzov S. V. Legalization of Buddhism in Orenburg Cossack Troops (1906-1917). Nauchnye vedomosti BelGU. Series 'History. Political Science. Economics. IT'. 2013. No. 22 (165). Is. 28. Pp. 121-127. (In Rus.)]

Златкин 1983 - Златкин И. Я. История Джунгарского ханства. М.: ГРВЛ, 1983. 332 с. [Zlatkin I. Ya. Istoriya Dzhungarskogo khanstva [A history of the Dzungar Khanate]. Moscow: Vost. Lit., 1983. 332 p. (In Rus.)]

История Калмыкии ... 2009 - История Калмыкии с древнейших времен до наших дней. Т. 1. Элиста: Издат. дом «Герел», 2009. 848 c. [Istoriya Kalmykii $s$ drevneyshikh vremen do nashikh dney [History of Kalmykia from the earliest times to the present days]. Vol. 1. Elista: Gerel, 2009. 848 p. (In Rus.)]

Калмыки 2010 - Калмыки. Том серии «Народы и культуры» / отв. ред. Э. П. Бакаева, Н. Л. Жуковская. М.: Наука, 2010. 568 с. [Kalmyki. Tom serii «Narody i kul'tury» [The Kalmyks. Series 'Peoples and Cultures']. E. P. Bakaeva, N. L. Zhukovskaya (eds.). Moscow: Nauka, 2010. 568 p. (In Rus.)]

Манжикова 2003 - Манжикова Л. Д. Очерки истории Большедербетовского улуса. Элиста: АПП «Джангар», 2003. 144 с. (ил). [Manzhikova L. D. Ocherki istorii Bol'shederbetovskogo ulusa [Essays on the history of Iki Dorbet District]. Elista: Dzhangar, 2003. 144 p. (In Rus.)]

Очиров 2008 - Очиров У. Б. К вопросу о терминах «зюн» и «барун» в этнической истории монгольских народов // Проблемы 
этногенеза и этнической культуры тюркомонгольских народов. Вып. 2. Элиста: Издво КалмГУ, 2008. С. 123-127. [Ochirov U. B. Revisiting the terms 'zün' and 'barun' in the ethnic history of the Mongols. Problemy etnogeneza $i$ etnicheskoy kul'tury tyurkomongol'skikh narodov. Is. 2. Elista: Kalmyk State Univ., 2008. Pp. 123-127. (In Rus.)]

Санчиров 2013 - Санчиров В. П. О происхождении основных ойратских этнонимов // Полевые исследования Калмыцкого института гуманитарных исследований РАН. Вып. 1. Ойраты Монголии: история и культура. Элиста: КИГИ РАН, 2013. C. 45-58. [Sanchirov V. P. Origins of the main Oirat ethnonyms revisited. Polevye issledovaniya Kalmytskogo instituta gumanitarnykh issledovaniy RAN. Is. 1. Oyraty Mongolii: istoriya i kul'tura [Oirats of Mongolia: history and culture]. Elista: Kalmyk Humanities Research Institute, 2013. Pp. 45-58. (In Rus.)]

Тишков - Тишков B. A. Этнос или этничность? [электронный pecypc] URL: http://www. valerytishkov.ru/cntnt/publikacii3/publikacii/ etnos_ili_html (дата обращения: 01.04.2018). [Tishkov V. A. Etnos ili etnichnost'? [Ethnos or ethnicity?]. An Internet resource: see hyperlink above (accessed: 1 April 2018). (In Rus.)]

Тишков 2016а - Тишков B. A. От этноса к этничности // Этнографическое обозрение. 2016 (a). № 5. C. 5-22. [Tishkov V. A. From ethnos to ethnicity. Etnograficheskoe obozrenie. 2016. No. 5. Pp. 5-22. (In Rus.)]

Тишков 20166 - Тишков B. A. Понимание и управление культурно-сложными обществами. СПб.: СПбГУП, 2016. 36 с., ил. (Избранные лекции университета. Вып. 172). [Tishkov V. A. Ponimanie i upravlenie kul'turnoslozhnymi obschestvami [Understanding and management of culturally diverse communities]. St. Petersburg: St. Petersburg Univ. of the Humanities and Social Sciences, 2016.36 p. (In Rus.)]

Чемчиева 2017 - Чемчиева А. П. Субэтнические группы алтайцев: противоречия и символы коллективной идентичности [электронный ресурс] // Новые исследования Тувы. 2017. № 1. URL: https://nit.tuva.asia/nit/article/ view/701 (дата обращения: 01.04.2018). [Chemchieva A. P. Sub-ethnic groups of the Altai people: contradictions and symbols of a collective identity. Novye issledovaniya Tuvy [The New Research of Tuva]. 2017. No. 1. An Internet resource: see hyperlink above (accessed: 1 April 2018). (In Rus.)]

Шантаев 2009а - Шантаев Б. А. О структуре родов калмыков-зюнгаров // Проблемы этнической истории и культуры тюркомонгольских народов. Вып. 1. Элиста: КИГИ РАН, 2009. С. 140-145. [Shantaev B. A. Kalmyks of the Zyungar association: clan structures. Problemy etnicheskoy istorii i kul'tury tyurko-mongol'skikh narodov. Is. 1. Elista: Kalmyk Humanities Research Institute, 2009. Pp. 140-145. (In Rus.)]

Шантаев 20096 - Шантаев Б. А. Этнотерриториальная группа хошутов Республики Калмыкия: история расселения и современное состояние // Проблемы этнической истории и культуры тюрко-монгольских народов. Вып. 1. Элиста: КИГИ РАН, 2009. С. 131139. [Shantaev B. A. The ethno-territorial group of Kalmykia's Khoshuts: history of allocation and present-day situation. Problemy etnicheskoy istorii i kul'tury tyurko-mongol'skikh narodov. Is. 1. Elista: Kalmyk Humanities Research Institute, 2009. Pp. 131-139. (In Rus.)]

Шараева 2003 - Шараева Т. И. Легенды о происхождении родов как источник по изучению субэтноса // Вестник института. Вып. 18. Элиста: АПП «Джангар», 2003. C. 279-282. [Sharaeva T. I. Legends about clan origins as sources for sub-ethnic studies. Vestnik instituta. Is. 18. Elista: Dzhangar, 2003. Pp. 279-282. (In Rus.)]

Шараева 2007a - Шараева Т. И. Род найнтахн: история происхождения названия // Проблемы этногенеза и этнической культуры тюрко-монгольских народов. Элиста: Изд-во Калм. ун-та, 2007. С. 84-88. [Sharaeva T. I. The Naintakhn clan: history of the clan name. Problemy etnogeneza $i$ etnicheskoy kul'tury tyurko-mongol'skikh narodov. Elista: Kalmyk State Univ., 2007. Pp. 84-88. (In Rus.)]

Шараева $2007 б$ - Шараева Т. И. Уран торгутов (полевые исследования) // Проблемы этногенеза и этнической культуры тюрко-монгольских народов. Элиста: Изд-во Калм. унта, 2007. C. 105-113. [Sharaeva T. I. The uran ('war-cry') of Torghuts. Problemy etnogeneza $i$ etnicheskoy kul'tury tyurko-mongol'skikh narodov. Elista: Kalmyk State Univ., 2007. Pp. 105--113. (In Rus.)]

Шараева 2008 - Шараева Т. И. Этническая группа Дунд хурла шевнр: фольклорные источники по истории возникновения групп (по данным полевых материалов) // Проблемы этногенеза и этнической культуры тюрко-монгольских народов. Вып. 2. Элиста: Изд-во КГУ, 2008. С. 158163. [Sharaeva T. I. The ethnic group of Dund Khurla Shevnr: folklore sources on the emergence of its clans (evidence from the 
author's field studies). Problemy etnogeneza $i$ etnicheskoy kul'tury tyurko-mongol'skikh narodov. Is. 2. Elista: Kalmyk State Univ., 2008. Pp. 158-163. (In Rus.)]

Шараева 2009 - Шараева Т. И. К вопросу об этническом составе аймака бурул и одноименной группы родов субэтнической группы дербетов-калмыков // Проблемы этнической истории и культуры тюрко-монгольских народов. Вып. 1. Элиста: КИГИ РАН, 2009. C. 124-130. [Sharaeva T. I. Revisiting the ethnic composition of the Buurul aimag ('a settled association of clans') and that of the cognominal clan group among Dorbet Kalmyks. Problemy etnicheskoy istorii i kul'tury tyurkomongol'skikh narodov. Is. 1. Elista: Kalmyk Humanities Research Institute, 2009. Pp. 124 130. (In Rus.)]

Шахбанова 2013 - Шахбанова М. М.Этническое самосознание и этническая идентичность: современные концепции исследования // Вестник института истории, археологии и этнографии. Махачкала: Институт истории, археологии и этнографии ДНЦ РАН, 2013. № 1. C. 135-147. [Shakhbanova M. M. Ethnic awareness and ethnic identity: contemporary research concepts. Vestnik instituta istorii, arkheologii $i$ etnografii. Makhachkala: Institute of History, Archaeology and Ethnography of Dagestan Scientific Center (RAS), 2013. No. 1. Pp. 135-147. (In Rus.)]

Шерстова 2006 - Шерстова Л. И. Алтайцы. Общие сведения. Этническая история // Тюркские народы Сибири / отв. ред. Д. А. Функ, Н. А. Томилов. М.: Наука, 2006. C. 375-391. [Sherstova L. I. The Altaians. General data. Ethnic history. Tyurkskie narody Sibiri [Turkic peoples of Siberia]. D. A. Funk, N. A. Tomilov (eds.). Moscow: Nauka, 2006. Pp. 375-391. (In Rus.)]

Эрдниев 1970 - Эрдниев У. Э. Калмыки. Историко-этнографические очерки. Элиста: Калм. кн. изд-во, 1970. 312 с. [Erdniev U. E. Kalmyki. Istoriko-etnograficheskie ocherki [The Kalmyks: historical and ethnographic sketches]. Elista: Kalm. Book Publ., 1970. 312 p. (In Rus.)]

\section{ИНТЕРНЕТ-РЕСУРСЫ / INTERNET RESOURCES}

Americans from Jungaria - Americans from Jungaria / Американцы из Джунгарии [электронный pecypc] // Produced and filmed by Norman Macki. Editor H. Johnston, script S. Johnston, with thanks to Noron Adianov, Nicolas Nembrikov, special commentary be
Arash Bormanchinov. URL: https:/www. youtube.com/watch? $\mathrm{v}=6 \mathrm{vFWeeq} 5 \mathrm{hTw}$ (дата обращения: 01.04.2018). [As aforesaid. An Internet resource: see hyperlink above (accessed: 1 April 2018). (In Eng., with Rus. subs.)]

Джунгария - больше... 2012 - Джунгария больше, чем землячество [электронный pecypc]//URL:http://www.kalmykianews. $\mathrm{ru} / 2012 / \mathrm{dzhungariya-bolshe-chem-}$ zemlyachestvo/ 13.02.2012. (дата обращения: 01.04.2018). [Dzhungariyabol'she, chem zemlyachestvo [Dzungaria - more than just an association of fellowkinsmen]. Posted on 13 February 2012. An Internet resource: see hyperlink above (accessed: 1 April 2018). (In Rus.)]

Калмыки - Калмыки [электронный ресурс] // URL: http://mediaknowledge. ru/1dfc238429aa8637.html (дата обращения: 29.01.2018). [Kalmyki [The Kalmyks]. An Internet resource: see hyperlink above (accessed: 29 January 2018). (In Rus.)]

POО Джунгария — РОО Джунгария калмыцкое землячество (Калмыкия) [электронный ресурс]. // URL: https://www.facebook.com/groups/ jungaria/; $\quad$ https://vk.com/djungaria (дата обращения: 01.04.2018). [ROO Dzhungariya - kalmytskoe zemlyachestvo (Kalmykiya) [Regional public organization 'Dzungaria' - a Kalmyk association of kinsmen]. An Internet resource: see hyperlink above (accessed: 1 April 2018). (In Rus.)]

Кто мы, ЗюнГары? - Кто мы, ЗюнГары? [электронный ресурс] // URL: https:// vk.com/topic-19394058_23384502 (дата обращения: 01.04.2018). [Kto my, ZyunGary? [Who are we? Dzungars?]. An Internet resource: see hyperlink above (accessed: 1 April 2018). (In Rus.)]

Ученые готовят ... 2007 — Ученые готовят международную научную экспедицию на прародину калмыков [электронный pecypc] // URL: http://forum. freekalmykia.org/index.php?/topic/607по-следам-джунгарии/ 13.06.2007. (дата обращения: 29.01.2018). [Uchenye gotovyat mezhdunarodnuyu nauchnuyu ekspeditsiyu na prarodinu kalmykov [Scientists are preparing an international research expedition to the ancestral lands of the Kalmyks]. Posted on 13 June 2007. An Internet resource: see hyperlink above (accessed: 29 January 2018). (In Rus.)] 
UDC 39

\title{
Ethnic Identity Issues of Kalmyk Buddhists in the 1900-1930s: a Perspective from the Current Challenges of Kalmyk Ethnic History Studies
}

Elza P. Bakaeva ${ }^{1}$

${ }^{1}$ Ph.D. in History (Doct. of Historical Sc.), Deputy Director, Kalmyk Scientific Center of the RAS (8, Ilishkin St, Elista, 358000, Russian Federation). ORCID: 0000-0002-5188-1202. E-mail: bakaevaep@ yandex.ru

\begin{abstract}
The article analyzes issues of ethnic and confessional identities in the contexts of challenges set forth by Kalmyk ethnic history studies. It examines a number of debated questions of Kalmyk ethnogenetic studies and the actively promoted (on the Internet) concepts of somewhat unified ethnic identity of the Kalmyks and Western Mongols (Oirats), as well as ideas about the formation of a unified Kalmyk identity in the early $20^{\text {th }}$ century. An insight into the reasons to explain the emergence of the latter included the use of documents stored at archival funds and dealing with activities of Kalmyk Buddhist communities in the early $20^{\text {th }}$ century. The paper shows that the ethnic identity to mirror common culture and origins of territorial groups inhabiting the Kalmyk Steppe before the 1900-1930s was actually 'supported' via multi-leveled self-identity processes within the confessional consciousness manifested in the then network of Buddhist monasteries and hierarchical structure of society. Contemporary views on recent formation of a unified Kalmyk identity stem from the available data confirming that during the period under consideration some common Kalmyk identity co-existed with a structurally different identity. The stratified ethnic identity mirrored in documents of Kalmyk Buddhists provides evidence of both somewhat preserved spatial borders of ethnic groups (resulting from peculiarities of the then administrative-territorial division) and the functions of mental (spiritual) markers performed by those borders.

In present-day Kalmykia, people keep searching for new mental markers which gives rise to the current interest in the early Oirat or even Mongolian periods of Kalmyk ethnic history. In this perspective, we witness another actualization of the term 'Dzungaria' which is often referred to (in Internet articles) as the ancestral area of the Kalmyks, and the Western Mongols tend to designate this concept as 'Oirat nutuq' (Kalm. 'hereditary / ancestral pasture lands'). Modern Kalmyk society also witnesses an increasing interest towards histories of clans. At the same time, processes of the $20^{\text {th }}$ century resulted in the fact that nowadays the confessional (Buddhist) identity lies beyond any ethnic divisions.
\end{abstract}

Keywords: ethnic identity, religious identity, Kalmyks, ethnic groups, Buddhists, documents 